\title{
Iron and zinc mycelial bioaccumulation in Agaricus subrufescens strains
}

\section{Bioacumulação micelial de ferro e zinco em linhagens de Agaricus subrufescens}

\author{
Suzana Harue Umeo ${ }^{1}$; Maria Graciela Iecher Faria ${ }^{2 *}$; Simone Schenkel Scheid \\ Vilande$^{1}$; Douglas Cardoso Dragunski ${ }^{3}$; Juliana Silveira do Valle ${ }^{2}$; Nelson Barros \\ Colauto $^{2}$; Giani Andrea Linde ${ }^{2}$
}

\begin{abstract}
Agaricus subrufescens, a basidiomycete native to Brazil, is worldwide cultivated due to its medicinal properties. This fungus is capable of bioaccumulating metals in the mycelial biomass when cultured in the presence of them; however, this capacity is little explored for functional food production. This study aimed to evaluate the amount of iron or zinc bioaccumulated in the vegetative mycelium of sixteen strains of A. subrufescens. Mycelia were grown in malt extract agar added with $50 \mathrm{mg} / \mathrm{L}$ of iron or with $7.5 \mathrm{mg} / \mathrm{L}$ of zinc. The metal bioaccumulation in the mycelial biomass was strain-dependent. In general, metal can inhibit or stimulate the mycelial growth ranging from -81 to $+78 \%$ for iron and from -86 to $+100 \%$ for zinc. The highest bioaccumulated iron and zinc concentrations in the mycelial biomass was $2,595.65 \mathrm{mg} / \mathrm{kg}$ and $1,655.83 \mathrm{mg} / \mathrm{kg}$, respectively and occurred in the U4-4 strain. The supplementation of mycelial biomass using iron or zinc is an alternative to develop food supplements, that can be used both in the human and animal diet and in the prevention of diseases.
\end{abstract}

Key words: Agaricus blazei. Agaricus brasiliensis. Iron. Metal. Mycelia. Translocation.

\section{Resumo}

Agaricus subrufescens, basidiomiceto nativo do Brasil, é cultivado mundialmente devido aos seus aspectos medicinais. Este fungo tem capacidade de bioacumulação de metais na biomassa micelial, no entanto, esta propriedade é pouco explorada para a produção de alimentos funcionais. O objetivo deste trabalho foi avaliar a quantidade de ferro ou zinco bioacumulada no micélio vegetativo de diversas linhagens de Agaricus subrufescens. Foram utilizadas 16 linhagens de $A$. subrufescens da coleção de culturas da Universidade Paranaense. O crescimento da biomassa micelial e a bioacumulação de ferro e zinco foram avaliados em micélio crescido em ágar extrato de malte adicionado de $50 \mathrm{mg} \mathrm{L}^{-1}$ de ferro ou 7,5 $\mathrm{mg} \mathrm{L}^{-1}$ de zinco. A bioacumulação dos metais na biomassa micelial foi linhagem dependente. De forma geral, os metais podem inibir ou estimular o crescimento com variação entre de -81 a $+78 \%$ para o ferro e de $-86 \mathrm{a}+100 \%$ para o zinco. A maior concentração de ferro na biomassa foi para o ferro de $2595,65 \mathrm{mg} \mathrm{kg}^{-1}$ e para o zinco de $1655,83 \mathrm{mg} \mathrm{kg}^{-1}$, ambos para a linhagem U4-4. O enriquecimento da

\footnotetext{
1 Discentes, Universidade Paranaense, UNIPAR, Laboratório de Biologia Molecular, Programa de Pós-Graduação em Biotecnologia Aplicada à Agricultura, Umuarama, PR, Brasil. E-mail: suzanaumeo@gmail.com; simone.scheid@edu.unipar.br

2 Profs., UNIPAR, Laboratório de Biologia Molecular, Programa de Pós-Graduação em Biotecnologia Aplicada à Agricultura, Umuarama, PR, Brasil. E-mail: maria.iecher@edu.unipar.br; jsvalle@prof.unipar.br; nbc@prof.unipar.br; gianilinde@prof. unipar.br

3 Prof., Centro de Engenharias e Ciências Exatas, Universidade Estadual do Oeste do Paraná, UNIOESTE, Toledo, PR, Brasil. E-mail: dcdragunski@gmail.com

* Author for correspondence
} 
biomassa micelial com ferro e/ou zinco é uma alternativa ao desenvolvimento de novos alimentos ou suplementos alimentares fonte de ferro e zinco de origem não-animal.

Palavras-chave: Agaricus blazei. Agaricus brasiliensis. Ferro. Metal. Micélio. Translocação.

\section{Introduction}

Agaricus subrufescens is native to Brazil and is cultivated worldwide (COLAUTO et al., 2010). It has antitumor (MOURÃO et al., 2009; BERTÉLI et al, 2014), anti-inflammatory (MOURÃO et al., 2011a) and antioxidant (MOURÃO et al., 2011b) activities and a high concentration of proteins (KAWAGISHI et al., 1989). It is capable of bioaccumulating metals in the mycelial biomass (MARCANTE et al., 2014) and it is a promising fungus for bioaccumulation studies.

Iron is an essential metal in human health because it is part of several metabolic processes (DUNN et al., 2007). Iron deficiency in the organism is a nutritional world problem, which affects more than 2 billion people, mostly youngsters, children and women at reproductive age living in developing countries (WHO, 2001). Generally, iron deficiency in the organism is followed by the lack of other micronutrients such as zinc (FAO, 2006). Zinc is involved in protein synthesis and is a regulator of synaptic activity and neuronal processes (ANDERSON; ERICKSON, 2011, p.423). Zinc deficiency due to the reduced ingestion of this metal causes an abnormal process in the nervous system with distinct behavioral effects (SANDSTEAD et al., 2000).

Basidiomycete fungi are capable of bioaccumulating metaland the production of mycelial biomass - enriched with iron or zinc - can be a source of metal from non-animal protein. The iron, zinc or selenium bioaccumulation in basidiocarps has been reported in some mushrooms species Iron or zinc bioaccumulation has been reported in basidiocarps but heavy metals and/or agrochemicals can be bioaccumulated from agricultural or agroindustrial residues utilized as cultivation substrate (BHATIA et al., 2013; VIEIRA et al., 2013; YOKOTA et al., 2016). Therefore, the mycelial biomass production allows better control of the substrate, the production period (MSHANDETE; MGONJA, 2009), and is a safer alternative for food production, concentrating nutritionally and pharmaceutically important metals (LEE et al., 2004).

The researches to reveal the function of bioactive compounds of $A$. subrufescens are extensive (WISITRASSAMEEWONG et al., 2012). Bertéli et al. (2014) studied the antineoplastic activity of different strains of $A$. subrufescens in sarcoma 180 with response variations in the strains. Umeo et al. (2015) reported variation of the antioxidant activity between the strains of $A$. subrufescens. That suggests that there is a great variability in the biological activity between the strains of the same species with biotechnological properties. Thus, this study aimed to evaluate the amount of iron or zinc bioaccumulated in the vegetative mycelium of sixteen A. subrufescens strains when cultivated on culture medium supplemented with $\mathrm{Fe}$ or $\mathrm{Zn}$.

\section{Material and Methods}

\section{Biological material}

Sixteen strains of Agaricus subrufescens Peck (Agaricus blazei Murrill ss. Heinemann; Agaricus brasiliensis Wasser et al.) of the Culture Collection of the Molecular Biology Laboratory of Paranaense University were utilized. Cryopreserved mycelia were recovered in $20 \mathrm{~g} / \mathrm{L}$ malt extract agar (MEA) medium (autoclaved at $121{ }^{\circ} \mathrm{C}$ for $20 \mathrm{~min}, \mathrm{pH}$ 6,0), in the dark at $25 \pm 1{ }^{\circ} \mathrm{C}$ (COLAUTO et al., 2008; MANTOVANI et al., 2012).

\section{Mycelial bioaccumulation of iron or zinc}

The solid cultivation medium consisted of MEA added with $\mathrm{FeSO}_{4}(50 \mathrm{mg} / \mathrm{L}$ of $\mathrm{Fe})$ or $\mathrm{ZnSO}_{4}(7.5$ $\mathrm{mg} / \mathrm{L}$ of Zn) (ALMEIDA et al., 2015; MARCANTE 
et al., 2014). MEA without the addition of metals was used as negative control. The cultivation medium was previously autoclaved $\left(121^{\circ} \mathrm{C}\right.$ for 20 min) and the solutions of $\mathrm{FeSO}_{4}$ or $\mathrm{ZnSO}_{4}$ were previously filtered $(0.22 \mu \mathrm{m}$ diameter pore $)$ then they were homogenized to the cultivation medium a little before poured into Petri dishes $(90 \mathrm{~mm})$. An MEA disk ( $0.5 \mathrm{~mm}$ of diameter) containing mycelia was inoculated in the middle of the cultivation medium and grown for 28 days at 28 $\pm 1{ }^{\circ} \mathrm{C}$ in the dark. The cultivation medium was heated up in a microwave oven for $30 \mathrm{~s}$ to remove the mycelial biomass from the surface of the cultivation medium using a caliper. The mycelial biomass was transferred to a $500 \mathrm{~mL}$ beaker containing $200 \mathrm{~mL}$ of ultrapurified water at $80^{\circ} \mathrm{C}$, and the mixture was agitated manually for $5 \mathrm{~min}$ to remove the residual cultivation medium. Next, the mycelial biomass was separated by centrifugation at $2900 \mathrm{~g}$ for $15 \mathrm{~min}$ at $4{ }^{\circ} \mathrm{C}$. The precipitate was transferred to a $50 \mathrm{~mL}$ beaker containing $20 \mathrm{~mL}$ of nitric acid $(10 \%)$ to remove metals adhered to the surface of the mycelial biomass. After that, the mycelial biomass was separated by centrifugation at $2900 \mathrm{~g}$ for $15 \mathrm{~min}$ at $4{ }^{\circ} \mathrm{C}$ and dried at $60{ }^{\circ} \mathrm{C}$ until constant mass.

\section{Determination of metals in the mycelial biomass}

The dried mycelial biomass was grounded in a mortar with a pestle, transferred to an Erlenmeyer $(125 \mathrm{~mL})$, mixed at a ratio of 1:12 (mass/volume) with $\mathrm{HNO}_{3}(67 \%)$ and kept for $72 \mathrm{~h}$ at $22{ }^{\circ} \mathrm{C} \pm 1$ ${ }^{\circ} \mathrm{C}$. The mixture was then heated at $100 \pm 1{ }^{\circ} \mathrm{C}$ for $10 \mathrm{~min}$ and added (1:6; mass/volume) with $\mathrm{H}_{2} \mathrm{O}_{2}$ (30\%) until obtaining the total solubilization of the mycelial biomass. The final volume of the solution was adjusted to $10 \mathrm{~mL}$ and filtered $(14 \mu \mathrm{m}$ pore filter paper). Fe or $\mathrm{Zn}$ concentrations in the samples were determined in a flame atomic absorption spectrophotometer (GBC model 932 plus) utilizing a standard curve to calculate the concentrations. All tests were done in triplicate. The bioaccumulated
$\mathrm{Fe}$ or $\mathrm{Zn}$ concentration in the mycelial biomass was calculated by subtracting the concentrations of the metal in the mycelial biomass grown in the cultivation media with or without the addition of each metal. The amount of translocated metal from the cultivation medium to the mycelial biomass was determined by multiplying the amount of dried mycelial biomass ( $\mathrm{mg}$ ) and the metal concentration contained in the dried mycelial biomass $(\mu \mathrm{g} / \mathrm{mg})$ per Petri dish. The arithmetical average and the standard deviation were calculated, and the data were submitted to Scott-Knott analysis $(p<0.05)$ utilizing Sisvar software, version 5.6.

\section{Results}

All strains were capable of producing mycelial biomass in cultivation medium with iron or zinc and bioaccumulating a greater amount of iron or zinc in the mycelial biomass when compared to the control (Tables 1 and 2). However, there was a great strain variation in the amount of mycelial biomass produced in relation to the type of metal added to the cultivation medium (Tables 1 and 2). This variation suggests that there is a strain-dependent response to the type of metal added, causing an inhibitory or stimulating effect in mycelial biomass yield. In general, there were more inhibited strains than stimulated ones with variation from -81 to $+78 \%$ for iron and from -86 to $+100 \%$ for zinc in the production of the mycelial biomass grown in the cultivation medium with iron or zinc (Tables 1 and 2). The concentration of iron or zinc in the mycelial biomass was greater for all the strains than the control, ranging from 1433 to $6534 \%$ (average of $3140 \%$ ) for iron, and from 872 to $3781 \%$ (average of $2173 \%$ ) for zinc. This makes evident that this species is capable of bioaccumulating iron or zinc in the mycelial biomass in a great amount (Tables 1 and 2). The metal bioaccumulation values demonstrate that there is a greater capability of iron bioaccumulation in the mycelial biomass than zinc in this species. 
The greater concentrations of bioaccumulated iron for U2-2 and U4-4 were 2,506.63 and 2,595.65 $\mathrm{mg} / \mathrm{kg}$, respectively (Table 1 ). Each strain had different responses regarding the mycelial biomass production. The U2-2 strain had a $37.8 \%$ reduction whereas U4-4 increased $52.9 \%$. The highest zinc concentrations in the mycelial biomass were $1,655.83 \mathrm{mg} / \mathrm{kg}$ for U4-4, followed by $915.47 \mathrm{mg} /$ $\mathrm{kg}$ for U6-16 (Table 2). Both strains did not present differences in the mycelial biomass production when grown in cultivation medium added with zinc. However, for U6-16 strain there was a decrease of $85.59 \%$ compared to the control without zinc addition. Despite being a combination of factors, the capacity of growing in cultivation medium with metal is more relevant than having a great capacity to translocate the metal to the mycelial biomass.

The strains showed the non-dependence between the capability of bioaccumulating iron or zinc and the mycelial biomass production. In general, there is a greater capacity to bioaccumulate iron than zinc in the mycelial biomass; however, there is a great response variation between the strains. While the presence of iron or zinc stimulated the mycelial biomass growth in some strains, it inhibited others.

\section{Discussion}

In our study, strains presented a distinct capacity to bioaccumulate iron or zinc, and U4-4 and U2-2 showed a great capacity to bioaccumulate iron and U4-4 to bioaccumulate zinc. A. subrufescens has already shown phenotypic variabilities in function of the strains. Bertéli et al. (2014) reported a 3.9fold variation in the antineoplastic activity between A. subrufescens strains, which were prepared and administered in the same way. Umeo et al. (2015) reported a 3.8-fold variation in the antioxidant activity among $A$. subrufescens strains. It shows that biological activity is usually specific for the strain and not for the species and how important it is to evaluate the biological activity of different strains of the same species. Similar studies comparing iron or zinc bioaccumulation in vegetative mycelia of $A$. subrufescens strains have not been found.

The iron concentration in the mycelial biomass was higher than the zinc ones for all strains. Marcante et al. (2014) studied zinc bioaccumulation in the mycelial biomass of A. subrufescens (U2-1) grown on solid medium added with $7.5 \mathrm{mg} / \mathrm{L}$ of zinc. For these authors, the maximum bioaccumulation was $414 \mathrm{mg} / \mathrm{kg}$. Our study demonstrates that when $7.5 \mathrm{mg} / \mathrm{L}$ of zinc was added to the solid cultivation medium, A. subrufescens (U4-4) bioaccumulated $1,655 \mathrm{mg} / \mathrm{kg}$ of zinc, that is 3.5 greater than the one reported by Marcante et al. (2014). For Almeida et al. (2015) concentrations of iron bioaccumulated in mycelial biomass were up to $3,616 \mathrm{mg} / \mathrm{kg}$ produced in submerged cultivation in Pontecorvo medium (PONTECORVO et al., 1953) added with yeast extract $(2.96 \mathrm{~g} / \mathrm{L}$ of nitrogen), glucose $(28.45 \mathrm{~g} / \mathrm{L})$ and iron $(250 \mathrm{mg} / \mathrm{L}$ of iron). The best results for iron bioaccumulation found in our study - without optimization - were 2,595 and $2,506 \mathrm{mg} / \mathrm{kg}$ for U4-4 and U2-2, respectively. 


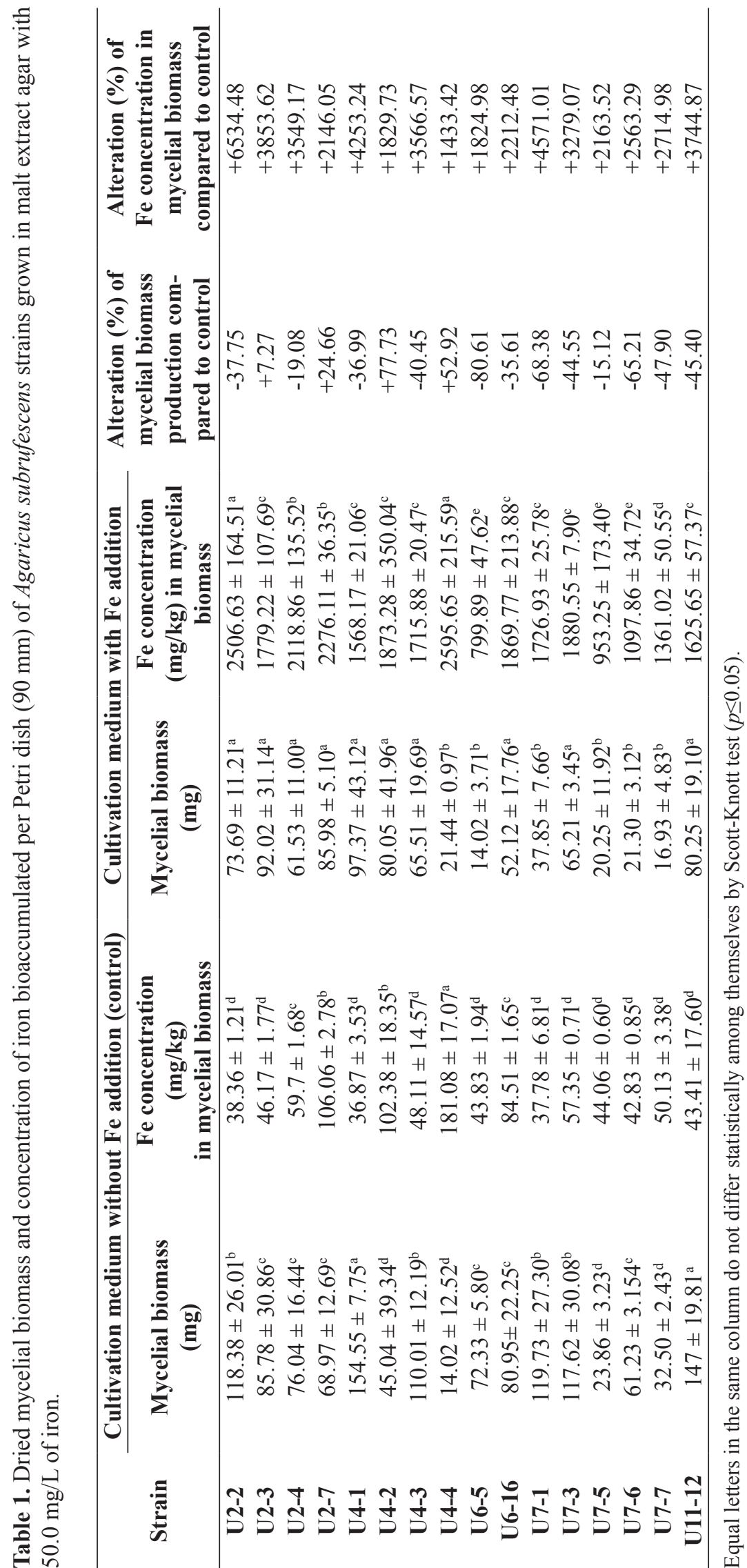




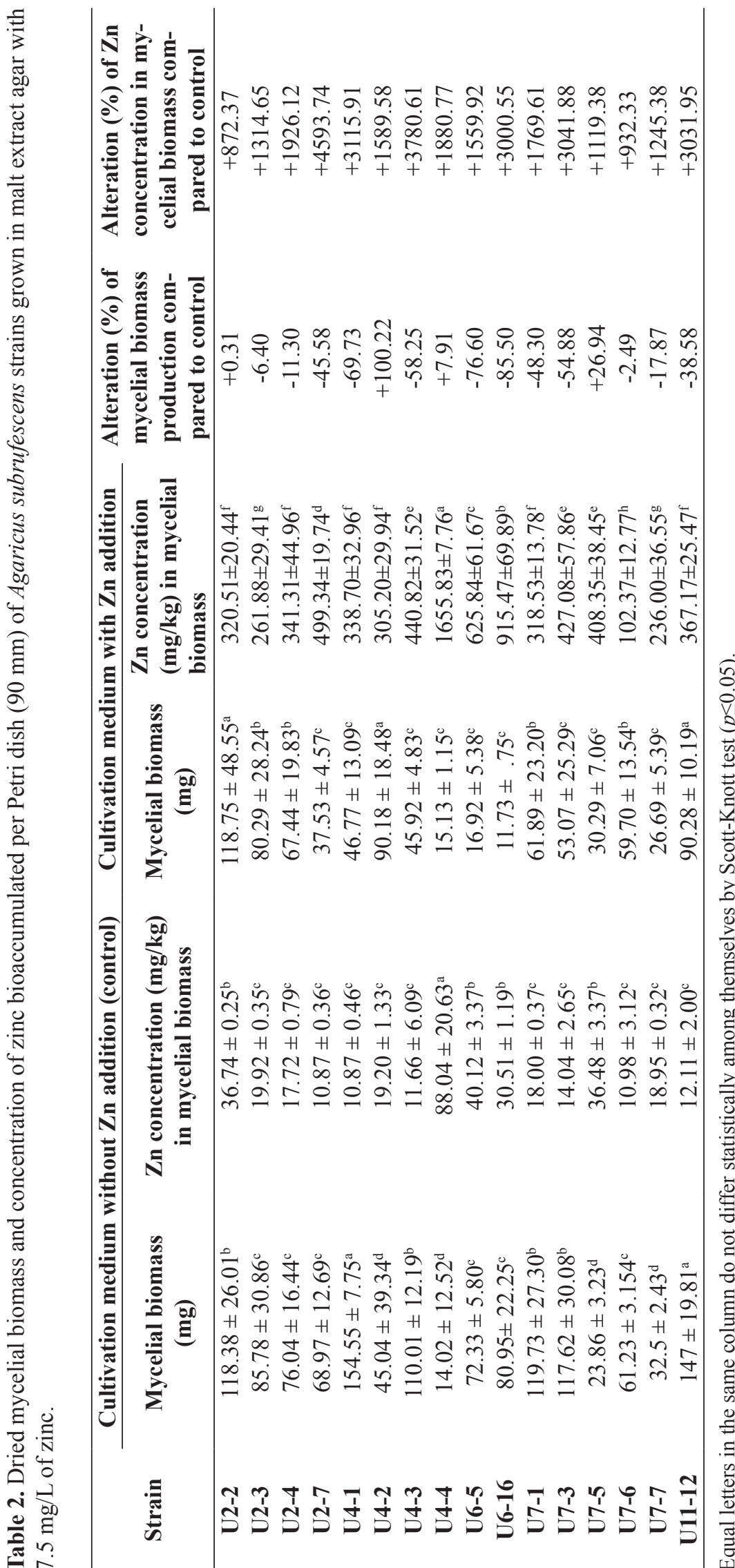


The greater capacity to bioaccumulate iron compared to zinc can be related to iron abundance in nature. According to Philpott (2006), iron is little soluble and, therefore, fungi can have created mechanisms to obtain and/or solubilize this metal. Basidiomycetes are able to produce siderophores to bioaccumulate iron, besides chelating molecules, such as catechols, carboxylates and hydroxamates (HAAS, 2003). It is believed that iron carriers can transport other metals, including zinc. On the other hand, high iron or zinc concentrations, $500 \mathrm{mg} / \mathrm{L}$ or 10 $\mathrm{mg} / \mathrm{L}$, respectively, in the cultivation medium inhibit fungal growth (YOKOTA et al., 2016; MARCANTE et al., 2014). Although iron is essential for fungal metabolism, when at high concentrations, it can release free radicals that can cause enzyme inhibition, displacement or substitution of essential ions, and membrane rupture that affect fungal metabolism and reproduction (GADD, 2007). Moreover, an energy orientation of the metabolism can occur to produce iron protective compounds and, therefore, reduce the energy utilized for fungal growth (HAAS, 2003).

The bioaccumulation of iron or zinc in $A$. subrufescens mycelial biomass can broaden the utilization of this fungus as functional food, besides its potential use in the prevention of osteoporosis, cholesterol, and circulatory and digestive properties (MIZUNO, 1995). Mycelial biomass - supplemented with metals - could benefit diets with reduced food of animal origin, poor in heme iron. Another aspect is that the main sources of food consumed by the general population have low zinc concentration such as $0.02 \mathrm{mg} / \mathrm{g}$ in beans, $0.025 \mathrm{mg} / \mathrm{g}$ in whole rice, $0.008 \mathrm{mg} / \mathrm{g}$ in chicken breast, and $0.03 \mathrm{mg} / \mathrm{g}$ in beef (PERES; KOURY, 2006). On the other hand, $1 \mathrm{~g}$ of bioaccumulated mycelial biomass contains $1.65 \mathrm{mg}$ of zinc, $98 \%$ more zinc than beef, the food with the highest natural zinc concentration.

\section{Conclusion}

Agaricus subrufescens strains are capable of producing mycelial biomass in the cultivation medium added with iron or zinc and also bioaccumulating iron or zinc. The inhibition or stimulation of the mycelial biomass production and the bioaccumulation of iron or zinc are straindependent. The fungus bioaccumulates a higher iron concentration than zinc with a maximum of $2,595.65 \mathrm{mg} / \mathrm{kg}$ for iron and $1,655.83 \mathrm{mg} / \mathrm{kg}$ for zinc. The enriching of mycelial biomass with iron or zinc is an alternative to the development of new foods or food supplements of a non-animal source.

\section{Acknowledgements}

The authors are very grateful to Coordenação de Aperfeiçoamento de Pessoal de Nível Superior - Brasil (CAPES) -finance code 001-, Conselho Nacional de Desenvolvimento Científico e Tecnológico (CNPq), Fundação Araucária, and Universidade Paranaense.

\section{Conflict of Interest}

The authors declare no conflict of interest.

\section{References}

ALMEIDA, S. M.; UMEO, S. H.; MARCANTE, R. C.; YOKOTA, M. E.; VALLE, J. S.; DRAGUNSKI, D. C.; COLAUTO, N. B.; LINDE, G. A. Iron bioaccumulation in mycelium of Pleurotus ostreatus. Brazilian Journal of Microbiology, São Paulo, v. 46, n. 1, p. 195-200, 2015. DOI: $10.1590 / \mathrm{S} 1517-838246120130695$

ANDERSON, J. G.; ERIKSON, K. M. The importance of trace elements for neurological function. In: PREEDY, V.; WATSON, R.; MARTIN, C. Handbook of behavior, food and nutrition. New York: Springer, 2011. p. 423439.

BERTÉLI, M. B. D.; UMEO, S. H.; BERTÉLI, A.; VALLE, J. S.; LINDE, G. A.; COLAUTO, N. B. Mycelial antineoplastic activity of Agaricus blazei. World Journal of Microbiology and Biotechnology, Netherlands, v. 30, n. 8 , p. $2307-2313$, 2014. DOI: $10.1007 / \mathrm{s} 11274-014-$ 1656-6

BHATIA, P.; PRAKASH, R.; PRAKASH, N. T. Selenium uptake by edible oyster mushrooms (Pleurotus sp.) from selenium-hyperaccumulated wheat straw. Journal of 
Nutritional Science and Vitaminology, Tokyo, v. 59, n. 1, p. 69-72, 2013. DOI: 10.3177/jnsv.59.69

COLAUTO, N. B.; AIZONO, P. A. M. C. M.; RIBEIRO, L.; PACCOLA-MEIRELlES, L. D.; LINDE, G. A. Temperature and $\mathrm{pH}$ conditions for mycelial growth of Agaricus brasiliensis on axenic cultivation. Semina: Ciências Agrárias, Londrina, v. 29, n. 2, p. 307-312, 2008.

COLAUTO, N. B.; SILVEIRA, A. R. D.; EIRA, A. F. D.; LINDE, G. A. Alternative to peat for Agaricus brasiliensis yield. Bioresource Technology, Miramar, v. 101, n. 2, p. 712-716, 2010. DOI: 10.1016/j.biortech.2009.08.052

DUNN, L. L.; RAHMANTO, Y. S.; RICHARDSON, D. $\mathrm{R}$. Iron uptake and metabolism in the new millennium. Trends in Cell Biology, Amsterdam, v. 17, n. 2, p. 93-100, 2007. DOI: 10.1016/j.tcb.2006.12.003

FOOD AND AGRICULTURE ORGANIZATION - FAO. Guidelines on food fortification with micronutrients. World Health Organization, Food and Agricultural Organization of the United Nations. Genebra: WHO, 2006.

GADD, G. M. Geomycology: biogeochemical transformations of rocks, minerals, metals and radionuclides by fungi, bioweathering and bioremediation. Mycological Research, Cambridge, v. 111, n. 1, p. 3-49, 2007. DOI: 10.1016/j.mycres.2006.12.001

HAAS, H. Molecular genetics of fungal siderophore biosynthesis and uptake: the role of siderophores in iron uptake and storage. Applied Microbiology and Biotechnology, Berlin, v. 62, n. 4, p. 316-330, 2003. DOI: 10.1007/s00253-003-1335-2

KAWAGISHI, H.; INAGAKI, R.; KANAO, T.; MIZUNO, T. Fractionation and antitumor activity of the water-in-soluble residue of Agaricus blazei fruiting bodies. Carbohydrate Research, Amsterdam, v. 186, n. 2 , p. 267-273, 1989. DOI: 10.1016/0008-6215(89)84040-6

LEE, B. C.; BAE, J. T.; PYO, H. B.; CHOE, T. B.; KIM, S. W.; HWANG, H.J.; YUN, J. W. Submerged culture conditions for the production of mycelial biomass and exopolysaccharides by the edible Basidiomycete Grifola frondosa. Enzyme and Microbial Technology, Amsterdam, v. 35, n. 5, p. 369-376, 2004. DOI: 10.1016/j. enzmictec.2003.12.015

MANTOVANI, T. R. D. A.; TANAKA, H. S.; UMEO, S. H.; ZAGHI-JUNIOR, L. L.; VALLE, J. S.; PACCOLAMEIRELLES, L. D.; LINDE, G. A.; COLAUTO, N. B. Cryopreservation at -20 and $-70{ }^{\circ} \mathrm{C}$ of Pleurotus ostreatus on grains. Indian Journal of Microbiology, v. 52, n. 3, p. 484-488, 2012. DOI: 10.1016/j.enzmictec.2003.12.015
MARCANTE, R. D. C.; MENIQUETTI, A.; PASCOTTO, C. R.; GAZIN, Z. C.; MAGALHÃES, H. M.; COLAUTO, N. B.; LINDE. G. A. Bioacumulação de zinco em micélio de Agaricus subrufescens. Arquivos de Ciências Veterinárias e Zoologia da UNIPAR, Umuarama, v. 17, n. 4, p. 249-252, 2014. DOI: 10.1016/j. enzmictec.2003.12.015

MIZUNO, T. Kawariharatake, Agaricus blazei Murill: medicinal and dietary effects. Food Reviews International, New York, v. 11, n. 1, p. 167-172, 1995. DOI: $10.1080 / 87559129509541026$

MOURÃO, F.; LINDE, G. A.; MESSA, V.; CUNHA JÚNIOR, P. L.; SILVA, A. V.; EIRA, A. F.; COLAUTO, N. B. Antineoplasic activity of Agaricus brasiliensis basidiocarps on different maturation phases. Brazilian Journal of Microbiology, São Paulo, v. 40, n. 4, p. 901905, 2009. DOI: 10.1590/S1517-83822009000400022

MOURÃO, F.; UMEO, S. H.; BERTÉLI, M. B. D.; LOURENÇO, E. L.; GASPAROTTO JUNIOR, A.; TAKEMURA, O. S.; LINDE, G. A.; COLAUTO, N. B. Anti-inflammatory activity of Agaricus blazei in different basidiocarp maturation phases. Food and Agricultural Immunology, United Kingdom, v. 22, n. 4, p. 325-333, 2011a. DOI: 10.1080/09540105.2011.581272

MOURÃO, F.; UMEO, S. H.; TAKEMURA, O. S.; LINDE, G. A.; COLAUTO, N. B. Antioxidant activity of Agaricus brasiliensis basidiocarps on different maturation phases. Brazilian Journal of Microbiology, São Paulo, v. 42, n. 1, p. 197-202, 2011b. DOI: 10.1590/ S1517-83822011000100024

MSHANDETE, A. M.; MGONJA, J. R. Submerged liquid fermentation of some Tanzanian basidiomycetes for the production of mycelial biomass, exopolysaccharides and mycelium protein using wastes peels media. ARPN Journal of Agricultural and Biological Science, Chak Shahzad Islamabad, v. 4, n. 6, p. 1-13, 2009.

PERES, P. M.; KOURY, J. C. Zinco, imunidade, nutrição e exercício. Ceres: Nutrição e Saúde, v. 1, n. 1, p. 9-18, 2006.

PHILPOTT, C. C. Iron uptake in fungi: a system for every source. Biochimica et Biophysica Acta (BBA) Molecular Cell Research, Amsterdam, v. 1763, n. 7, p. 636-645, 2006. DOI: 10.1016/j.bbamcr.2006.05.008

PONTECORVO, G.; ROPER, J. A.; CHEMMONS, L. M.; MACDONALD K. D., BUFTON, A. W. J. The Genetics of Aspergillus nidulans. Advances in Genetics, Amsterdam, v. 5, p. 141-238, 1953. 10.1016/S00652660(08)60408-3

SANDSTEAD, H. H.; FREDERICKSON, C. J.; PENLAND, J. G. History of zinc as related to brain 
function. The Journal of Nutrition, Bethesda, v. 130, n. 2S, p. 496S-502S, 2000. DOI: 10.1093/jn/130.2.496S

UMEO, S. H; SOUZA, G. P. N.; RAPACHI, P. M.; GARCIA, L. D.; PACCOLA-MEIRELLES, L. D.; VAllE, J. S.; COLAUTO, N. B.; LINDE, G. A. Screening of basidiomycetes in submerged cultivation based on antioxidant activity. Genetics and Molecular Research, Ribeirão Preto, v. 14, n. 3, p. 9907-9914, 2015. DOI: $10.4238 / 2015$.August.19.25

VIEIRA, P. A. F.; GONTIJO, D. C.; VIEIRA, B. C.; FONTES, E.A.F.; ASSUNÇÃO, L. S.; LEITE, J. P. V.; OLIVEIRA, M. G. A.; KASUYA, M. C. M. Antioxidant activities, total phenolics and metal contents in Pleurotus ostreatus mushrooms enriched with iron, zinc or lithium. LWT - Food Science and Technology, Amsterdam, v. 54, n. 2, p. 421-425, 2013. DOI: 10.1016/j.lwt.2013.06.016
WISITRASSAMEEWONG, K.; KARUNARATHNA, S. C.; THONGKLANG, N.; ZHAO, R.; CALLAC, P.; MOUKHA, S.; FERANDON, C.; CHUKEATIROTE, E.; HYDE, K. D. Agaricus subrufescens: a review. Saudi Journal of Biological Sciences, Chiang Rai, v. 19, n. 2, p. 131-146, 2012. DOI: 10.1016/j.sjbs.2012.01.003

WORLD HEALTH ORGANIZATION - WHO. Iron deficiency anaemia: assessment, prevention and control: a guide for programme managers. Geneva: World Health Organization, 2001.

YOKOTA, M.; FRISON, P.; MARCANTE, R.; JORGE, L. F.; VALLE, J. S.; DRAGUNSKI, D. C.; COLAUTO, N. B.; LINDE, G. A. Iron translocation in Pleurotus ostreatus basidiocarps: production, bioavailability, and antioxidant activity. Genetics and Molecular Research, Ribeirão Preto, v. 15, n. 1, p. 1-10, 2016. 
